\title{
ASAP1 wt Allele
}

National Cancer Institute

\section{Source}

National Cancer Institute. ASAP1 wt Allele. NCI Thesaurus. Code C118598.

Human ASAP1 wild-type allele is located within 8q24.1-q24.2 and is approximately $392 \mathrm{~kb}$ in length. This allele, which encodes Arf-GAP with SH3 domain, ANK repeat and PH domain-containing protein 1 , is involved in the regulation of phosphoinositol-mediated signaling. 